\title{
COMPARATIVE ANALYSIS OF USERS PERCEPTION FOR ROAD CONCESSIONING AND TOLLING USING MULTINOMIAL REGRESSION AND ARTIFICIAL NEURAL NETWORK
}

\author{
Adanikin Ariyo $^{1^{*}}$, Falade Funsho Alphonsus ${ }^{2}$, Oyedepo Olugbenga Joseph ${ }^{3}$, Adewale Olutaiwo ${ }^{2}$ \\ ${ }^{1}$ Department of Civil and Environmental Engineering, \\ Elizade University, Ilara-Mokin, NIGERIA \\ ${ }^{2}$ Department of Civil and Environmental Engineering, \\ University of Lagos, Akoka, NIGERIA \\ ${ }^{3}$ Department of Civil and Environmental Engineering, \\ Federal University of Technology Akure, NIGERIA
}

\begin{abstract}
Roads, a predominant means of transportation in developing countries like Nigeria have suffered neglect and are in deplorable conditions due to inadequate funding by the government. However, road concessioning have not been widely accepted in Nigeria due to limited understanding by road users. The 49.5 km Lekki-Epe Road (LER) and 1.36 km LekkiIkoyi cable-stayed Link Bridge (LILB) concession road were selected for detailed study. Closed and open ended questionnaires were administered to road users and analyzed. The study findings show that majority of the road users are civil servants, non-resident in the study area and are high-end users of the roads. Also, home based trip purpose, use of personal vehicles, preference for paying the toll fees in cash regardless of the discounts offered on $E$ Tags was observed among the respondents. Consequently, majority of the road users complained of non-availability of alternative routes, being overtaxed especially when having to use the roads multiple times in a day. The use of fuel tax in financing highway construction and maintenance, and that neither new nor existing highways should be tolled also constitute feedbacks from road users. The study recommends that other options of road infrastructure financing such as the Build, Operate and Transfer should also be considered, and the tolling concessioning period needs to be properly defined. Also, multimodal systems of transportation should also be enhanced in developing countries to alleviate the stress imposed on road pavements that thereby hastens their deterioration.
\end{abstract}

Keywords: transportation, road users, concessioning, tolling, multimodal systems

\section{INTRODUCTION}

Road, a long-term infrastructure investment has become the most used means of transportation in Nigeria due to the collapse of railways, nondevelopment of waterways and the limited investment on airways. The increasing demand for road transportation due to rapid urbanization increases the stress on the existing and poorly maintained road network; this results in their failure or deterioration. Though, a well-managed, efficient and effective road network system couple with strict adherence to traffic rules is therefore fundamental to the safety of the road users.

According to (Brushett, 2005), the predominance of road transport as the means of passenger and freight movements in Sub-Saharan Africa underlines the economic importance of roads. He opined that the costs of degraded road network to road users are very high and consequently hinder national economic development potential which translates into higher vehicle operating costs and increase travel times (Brushett, 2005). Also, Adanikin and Oyedepo (2017) affirmed that effective and efficient multimodal transport system is a catalyst for economic development; while, road networks is considered as an asset which needs to be maintained and improved in order to ensure the best performance, value-for-money and the maximum service-life (Harral et al., 2011). Thus, well maintained road networks that provide the level of service needed by road users are critical and important elements of development (Pojani \& Stead, 2015). 


\section{International Journal of Engineering Applied Sciences and Technology, 2020 \\ Vol. 4, Issue 10, ISSN No. 2455-2143, Pages 363-371 \\ Published Online February 2020 in IJEAST (http://www.ijeast.com)}

An infrastructure concession refers to a contract under the terms of which a public authority accords specific rights to a company to construct, maintain and/or operate a network for a given period. Concessioning is a mechanism that allows the private sector takes full responsibility for operating and investing in infrastructure services and therefore takes on significant commercial risks (Jerome, 2004). Cconcessioning contract entails the transfer of responsibility (risks) from the Concession Authority to the Concessionaire (ASECAP, 2014). The government retains ownership of the asset, but the private operator retains ownership over any improvements made during the concession period (RICS 2011). The main components of a concession contract are: lot size, concession period, toll charges, concession award criteria, potential for development of new ideas by the concession company and sharing of risks between the concession authority and concession company. In road construction projects, the resources (human and capital), ability and financial capacity of a concessionaire to fulfil its contractual obligations and responsibilities is vital (Wong et al., 2000). Inability of concessionaires to fulfil these requirements has led to their inability to successful complete construction projects allotted to them. The Infrastructure Concession Regulatory Commission (ICRC) Act 2005 is responsible for setting forth guidelines to promote, facilitate and ensuring Public Private Participation (PPP) projects in Nigeria. Concession agreement models under the infrastructure law includes the following: Infrastructure Financing; Design, Build, Operate and Transfer (DBOT); Build, Own, Operate and Transfer (BOOT); Rehabilitate, Operate and
Transfer (ROT); Joint Development Agreement (JDA); Operation and Maintenance (OM); Management Contract; and Leasing.

Loto and Nkaogu (2013) asserted that the

Nigeria government spends $\$ 2.25 \mathrm{tr}$ (\$15bn) annually to improve road network to an acceptable level, which is about $25.48 \%$ of her budget. The implication is that this huge requirement to finance infrastructure will involve the participation of private partnerships to stimulate the economy; considering the global decline in oil price that is a major source of revenue for the Nigerian government. This is in contrary to Opawole et al., (2013), which opined that public-private partnership (PPP) financing initiative for road infrastructure development in Nigeria, has only attracted less significant private sector participation. However, in Western Europe, the concession system practice in the road sector shows that of a total of $51,242 \mathrm{~km}$ of motorway, 17,009 $\mathrm{km}$ are under concession (33\%), of which $16,356 \mathrm{~km}$ are on a toll, and $653 \mathrm{~km}$ on a shadow toll basis (IER, 2001). In contrast, Nigeria only have two concession and tolled roads namely the Lekki-Epe Expressway $(49.36 \mathrm{~km})$ and the Admiralty Bridge $(1.358 \mathrm{~km})$ both located in Lagos State after several failed road concessions. The concessioned roads are being managed by Lekki Concession Company (LCC), a special purpose vehicle (SPV) chosen under the DBOT arrangement. Road concessioning is quite challenging with many parties involved in the planning, design and execution of the varied project construction and maintenance stages. This is exemplified by the Lekki toll road contractual structure as shown in Figure 1.

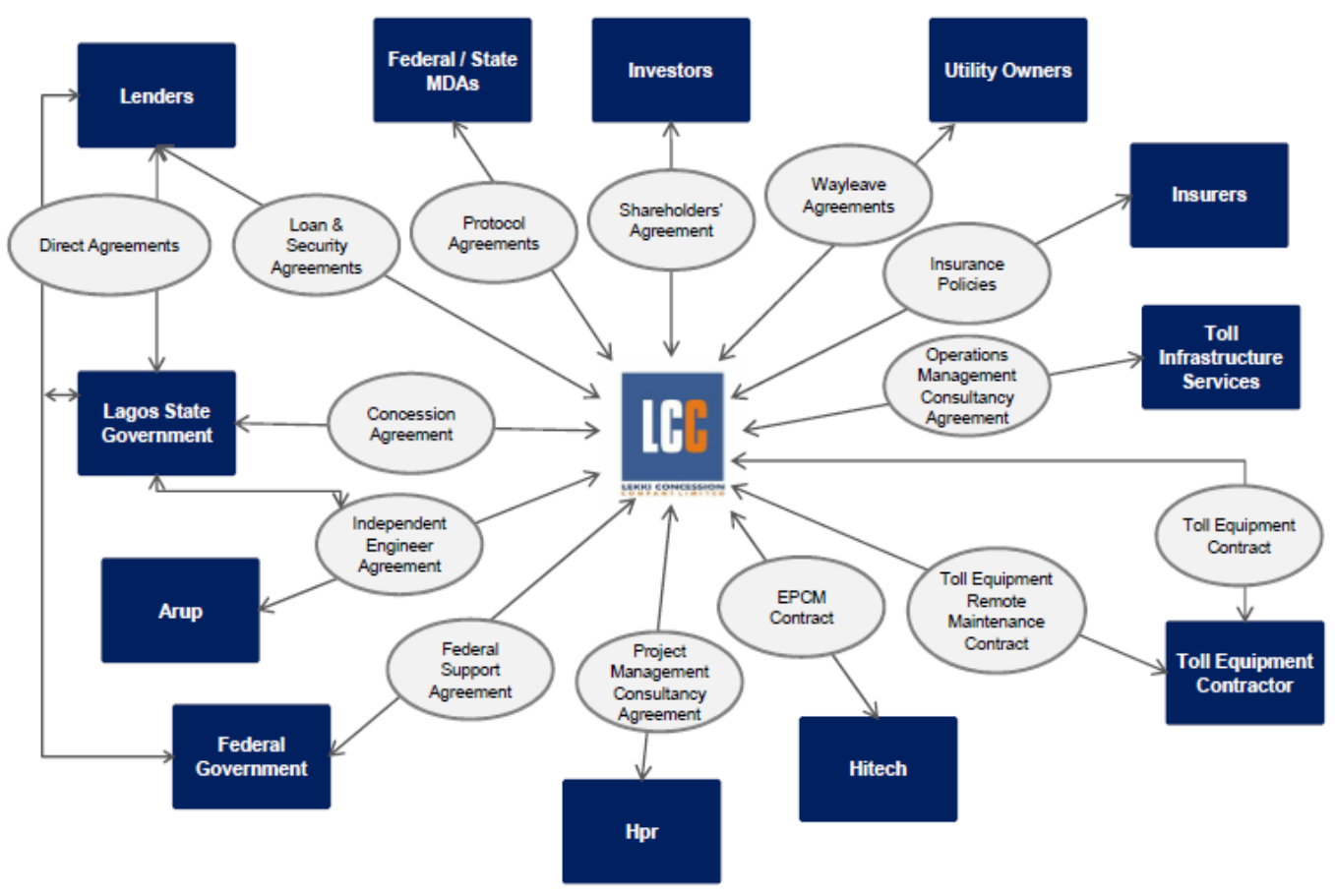

Figure 1: Lekki toll road contractual structure, Source: Opuiyo (2015) 


\section{International Journal of Engineering Applied Sciences and Technology, 2020 \\ Vol. 4, Issue 10, ISSN No. 2455-2143, Pages 363-371 \\ Published Online February 2020 in IJEAST (http://www.ijeast.com)}

Table 1 shows the two concession roads in Lagos state while Table 2 is the concession but abandon projects by the Federal and State government in Nigeria. The failure of road concession agreements in Nigeria has led to further deterioration of road pavements, increasing accidents on the roads, loss of man-hours and productivity for the nation's ailing economy. However, the study carried out the comparative analysis of user's perception for road concessioning and tolling using multinomial regression and artificial neural network.

Table 1: Concession and Tolled Roads in Nigeria

\begin{tabular}{|c|c|c|c|c|c|}
\hline Road & Concessionaire & Concession & Km. of Road & $\begin{array}{l}\text { Concession } \\
\text { Nature }\end{array}$ & Year \\
\hline Lekki-Epe & Lekki Concession & Lagos State & $49.36 \mathrm{~km} \mathrm{(50)}$ & 30 Years & $2007-$ \\
\hline Expressway & Company (LCC) & Government & Billion Naira) & (DBOT) & 2037 \\
\hline Admirality & Lagos Tolling & Lagos State & $1.358 \mathrm{~km}(29$ & 25 Years & 2013- \\
\hline Bridge, Lagos & Company (LTC) & Government & Billion Naira) & (DBOT) & 2038 \\
\hline
\end{tabular}

Table 2: Failed Concession Roads in Nigeria

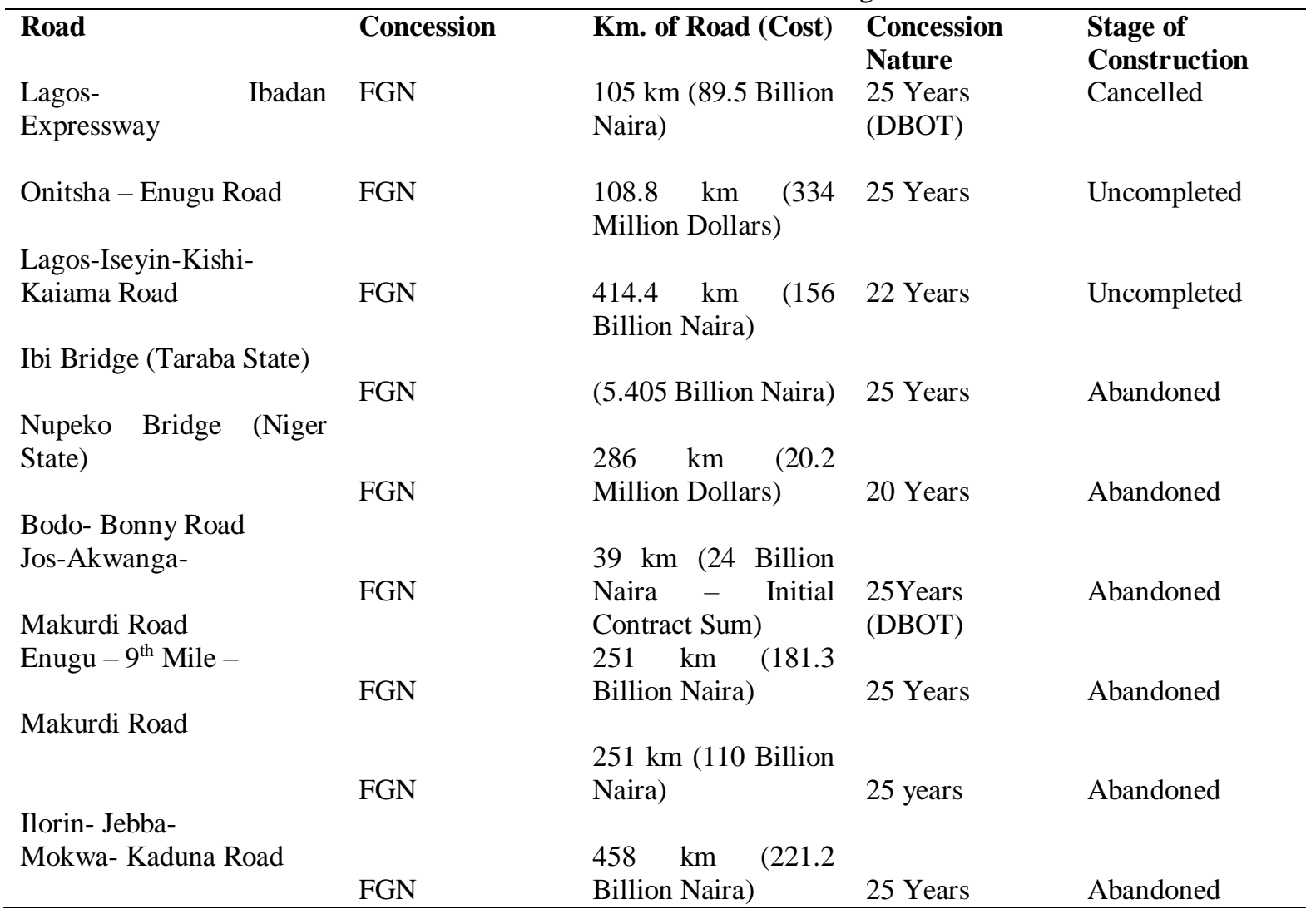

*FGN- Federal Government of Nigeria.

\section{THE STUDY AREA}

The study area is located within Lagos state, Nigeria. With a population of approximately 16 million, Lagos is the most populous city in Nigeria and one of the fastest growing in the world (Wikipedia, 2019). One million motor vehicles are estimated to be stationed in Lagos with a daily traffic flow between Lagos Mainland and Lagos Island of about 500,000 motor vehicles. The poor condition of roads throughout Lagos is characterized by crumbling sidewalks, badly pot-holed road surfaces,
Source: Researchers Study (2019)

non-functional traffic lights, poor signage, and blocked or non-existent drainage systems. The 2004 Lagos State "Roads Law" establishes the enabling framework for projects such as the Lekki Toll Road Concession.

The selected privately-financed toll roads operated by Lekki Concession Company (LCC) in Lagos state Nigeria are the $49.5 \mathrm{~km}$ Lekki-Epe Road (LER) and $1.36 \mathrm{~km}$ Lekki-Ikoyi cable-stayed Link Bridge (LILB). The road concession is a Public Private Partnership (PPP) scheme which, uses the Build-Operate-Transfer (BOT) model of 


\section{International Journal of Engineering Applied Sciences and Technology, 2020 \\ Vol. 4, Issue 10, ISSN No. 2455-2143, Pages 363-371 \\ Published Online February 2020 in IJEAST (http://www.ijeast.com)}

Infrastructure delivery. The concession is for a period of 30 years, following which the assets will be transferred to Lagos State Government. The concessioner is to among other things construct, upgrade, expand and maintained the roads, they also provide facilities and services to improve the safety of road users among others things. The project benefits are improved convenience, reduced journey times, enhanced safety, security, and a better driving experience. Figures 2 and 3 shows the photograph of the two road with the toll gates/bridges.

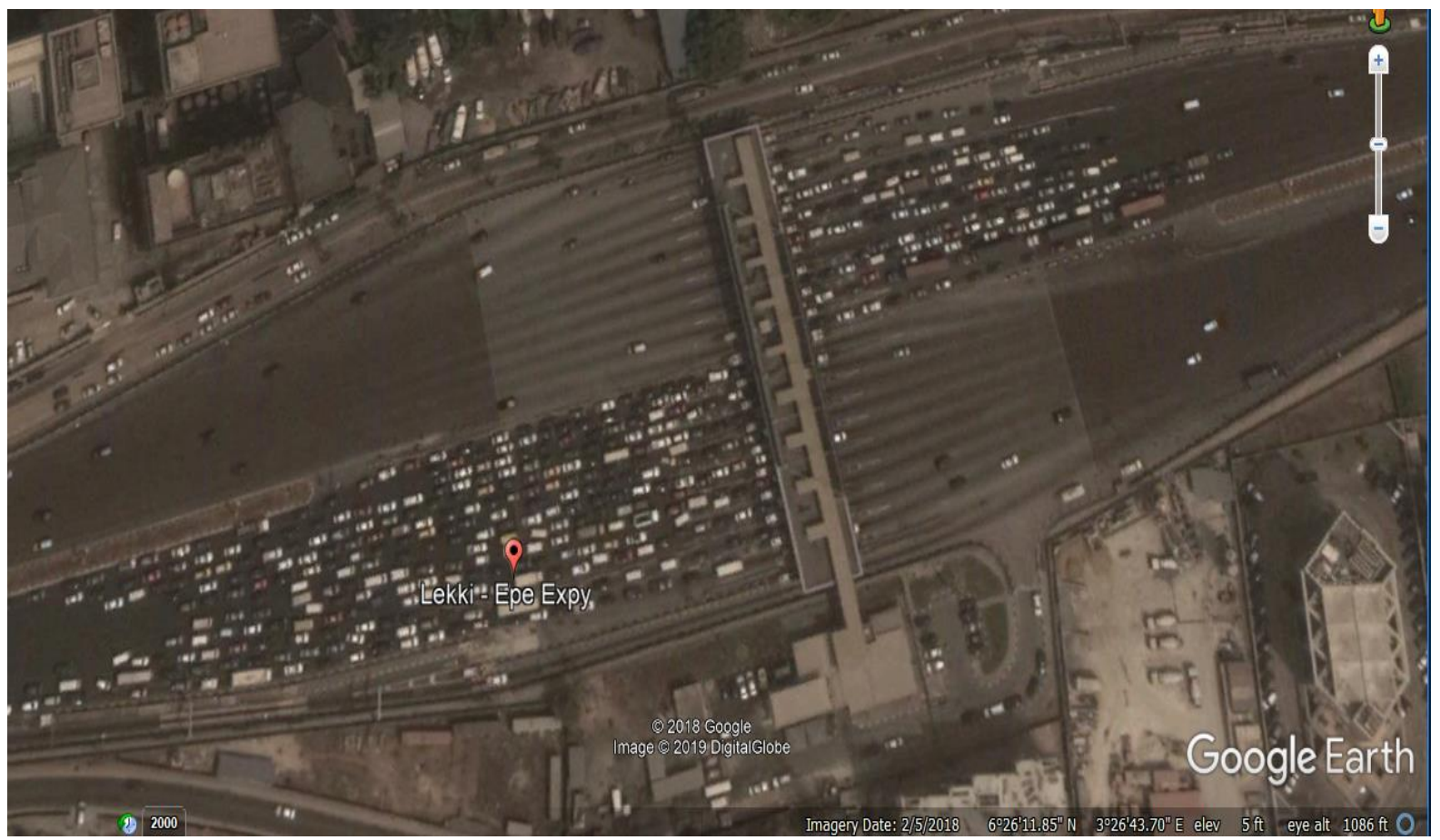

Figure 2: Aerial View Showing Admiralty Toll Plaza

Source: Google Earth, 2019

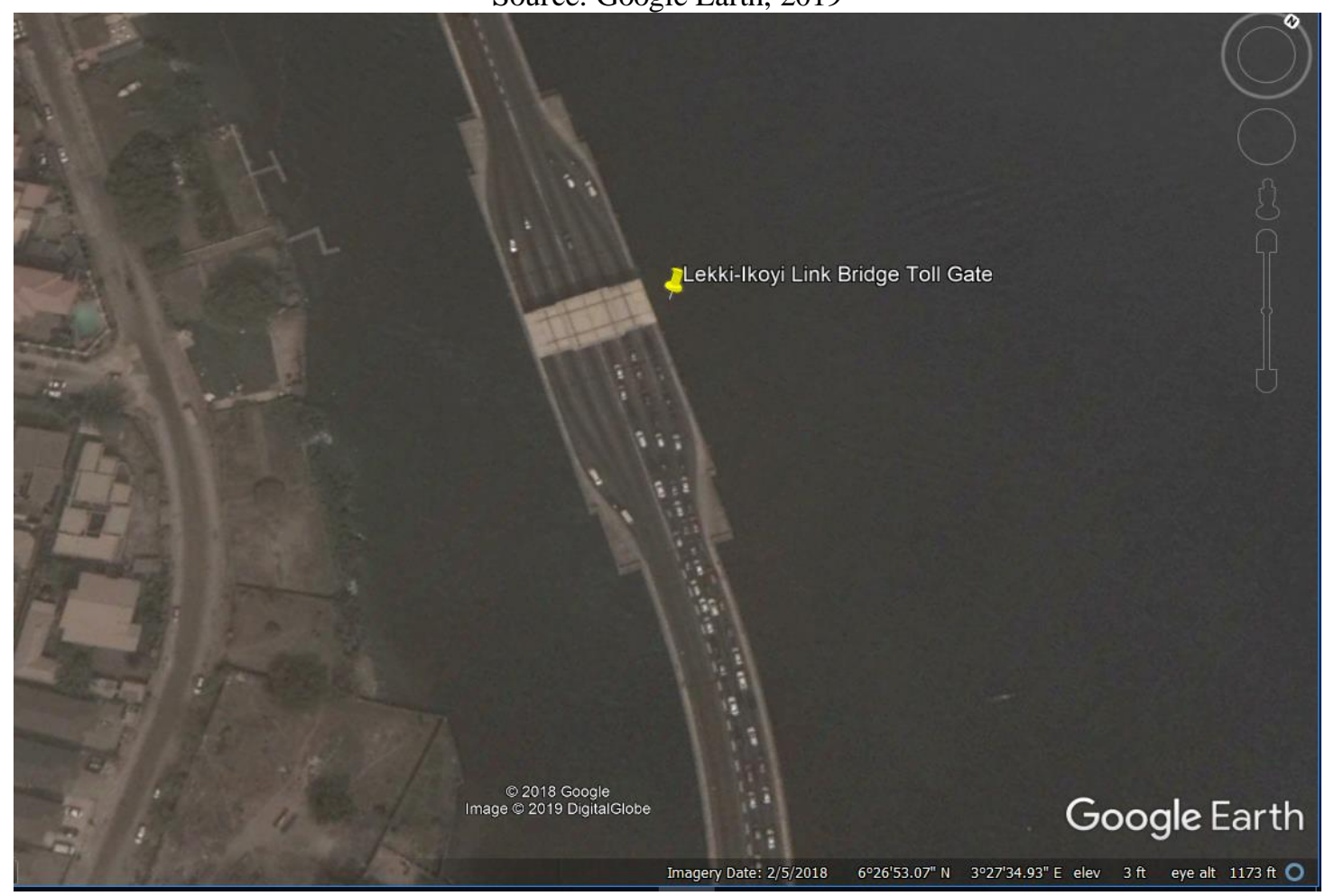

Figure 3: Aerial View Showing Ikoyi Bridge Toll Plaza Source: Google Earth, 2019 
The tolling of the road development is being undertaken to enable the concessionaires to recover the investment it made in the scheme having accessed funds from the foreign counterparts. The tolling system for the road is as shown in the Table 3 alongside price changes for different years.

Table 3: Toll charges on the Concessioned Roads.

\begin{tabular}{|c|c|c|c|c|c|}
\hline \multirow{3}{*}{$\begin{array}{l}\text { Vehicle } \\
\text { Class }\end{array}$} & \multirow[t]{3}{*}{ Description } & \multicolumn{4}{|c|}{ Standard Toll Tariff } \\
\hline & & \multicolumn{2}{|c|}{ Admiralty Circle Plaza Tariff } & \multicolumn{2}{|c|}{$\begin{array}{c}\text { Lekki-Ikoyi Link Bridge Plaza } \\
\text { Tariff }\end{array}$} \\
\hline & & 2012 & 2019 & 2017 & 2019 \\
\hline Class M & Motorcycles & N50 & 100 & 100 & 200 \\
\hline Class I & Saloon cars and tricycles & N120 & 200 & 250 & 300 \\
\hline Class II & $\begin{array}{l}\text { Sports Utility Vehicles } \\
\text { (SUVs), minibuses and } \\
\text { pickup trucks } \\
\text { Commercial Danfo } \\
\text { minibuses }\end{array}$ & N150 & 250 & 300 & 400 \\
\hline $\begin{array}{l}\text { Class IIA } \\
\text { Class }\end{array}$ & $\begin{array}{l}\text { Light trucks and } 2 \text { axle } \\
\text { buses }\end{array}$ & N80 & 100 & 400 & - \\
\hline Class IV & $\begin{array}{l}\text { Heavy trucks and buses } \\
\text { with two or more heavy } \\
\text { axles }\end{array}$ & $\mathrm{N} 250$ & 400 & & 1000 \\
\hline
\end{tabular}

\section{METHODOLOGY}

Reconnaissance surveys were carried out throughout the study area to examine the behaviour of operators and users. A descriptive research survey was employed which enabled the required data to be collected by administering a well-structured questionnaire to vehicle owners. A total of 400 questionnaires were distributed. The questionnaire consist of questions with options from which respondents are expected to pick response as applicable (close-ended) and questions which allow respondents to freely express their opinion on the subject matter (open-ended). The respondents were surveyed using triangulation sampling technique based on the consideration to examine at least half $(50 \%)$ of the total study population. A total of 347 $(87 \%)$ questionnaires were retrieved for data analysis. Data obtained were analysed using Statistical Package for Social Sciences version 22 (SPSS 22) to formulate a predictive model using Multiple Regression and Artificial Neural Network (Multilayer Perceptron). Figure 4 is a map showing the study area.

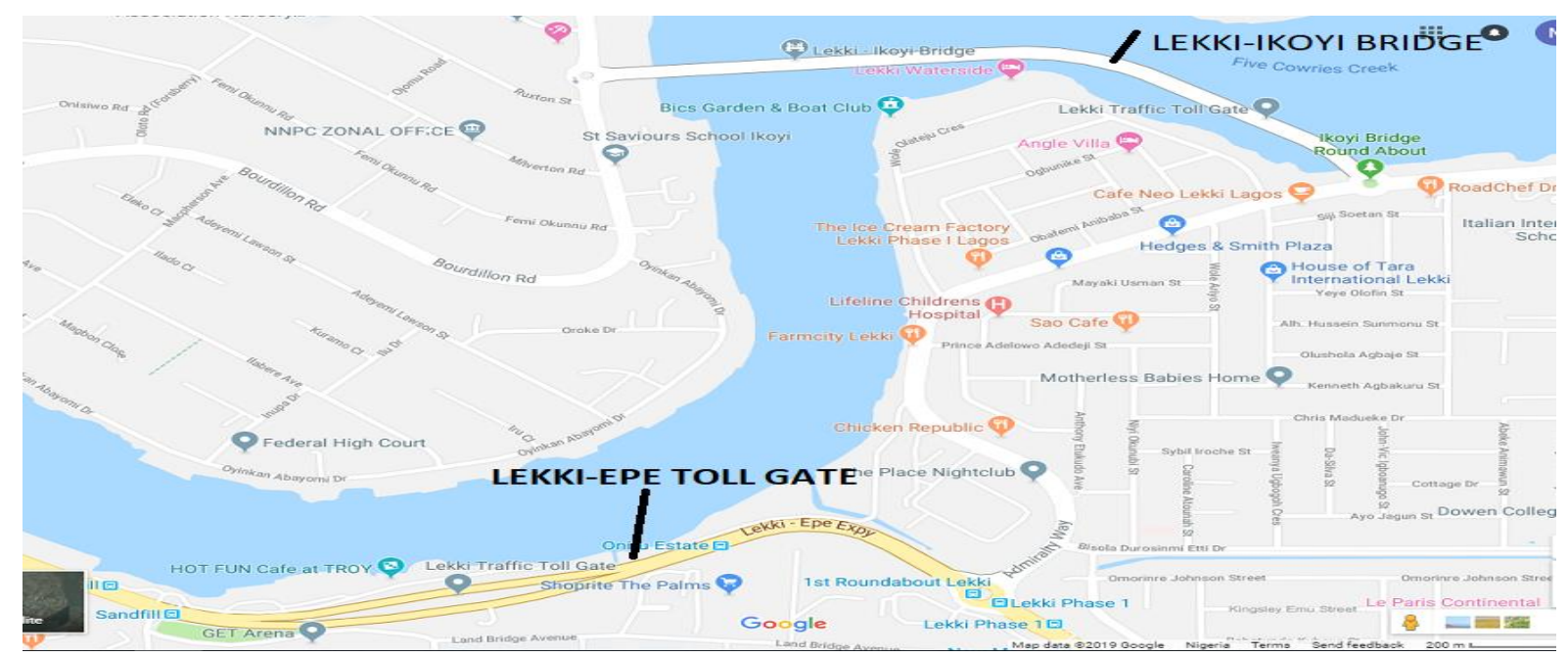

Figure 4: Google Map image of the study area. 


\section{RESULTS AND DISCUSSION}

Table 4 show the descriptive analysis of the road users response.

Table 4: Descriptive response of road user

\begin{tabular}{|c|c|c|c|}
\hline \multicolumn{2}{|l|}{ Demographic and Personal Information } & \multicolumn{2}{|c|}{ Population of Respondents } \\
\hline Variable & Information & Frequency (N) & Percentage (\%) \\
\hline \multirow{4}{*}{ Occupation } & Civil Servant & 153 & 44.1 \\
\hline & Unemployed & 46 & 13.3 \\
\hline & Self employed & 88 & 25.4 \\
\hline & Student & 60 & 17.3 \\
\hline \multirow[t]{2}{*}{ Resident / Non Resident in the Area } & Yes & 130 & 37.5 \\
\hline & No & 217 & 62.5 \\
\hline \multirow[t]{3}{*}{ How often do you use the route } & Low & 40 & 11.5 \\
\hline & Medium & 114 & 32.9 \\
\hline & High & 193 & 55.6 \\
\hline \multirow{3}{*}{ Purpose of trip } & Resident & 139 & 40.1 \\
\hline & Business & 123 & 35.4 \\
\hline & Leisure & 89 & 24.5 \\
\hline \multirow[t]{2}{*}{ Type of Vehicle } & Personal & 189 & 54.5 \\
\hline & Commercial & 158 & 45.5 \\
\hline \multirow[t]{2}{*}{ Mode of Toll Payment } & Cash & 246 & 70.9 \\
\hline & E-Tag & 101 & 29.1 \\
\hline \multirow{2}{*}{$\begin{array}{l}\text { Availability of Alternative Route to } \\
\text { Destination }\end{array}$} & Yes & 86 & 24.8 \\
\hline & No & 261 & 75.2 \\
\hline \multirow{2}{*}{$\begin{array}{l}\text { Love to see other roads in Lagos } \\
\text { concession and tolled }\end{array}$} & Yes & 107 & 30.8 \\
\hline & No & 240 & 69.2 \\
\hline \multirow{4}{*}{$\begin{array}{l}\text { How should highway construction and } \\
\text { maintenance be financed }\end{array}$} & Fuel Tax & 162 & 46.7 \\
\hline & Road Tolls & 58 & 16.7 \\
\hline & Donors & 62 & 17.9 \\
\hline & Consolidated Funds & 65 & 18.7 \\
\hline \multirow{4}{*}{$\begin{array}{l}\text { Which category of highways could be } \\
\text { tolled }\end{array}$} & New Highways & 112 & 32.3 \\
\hline & Existing Highways & 62 & 17.9 \\
\hline & Both & 51 & 14.7 \\
\hline & None & 122 & 35.2 \\
\hline
\end{tabular}

As shown in Table 4, the distribution of the respondents by occupation shows that majority of the respondents were civil servants $(44.1 \%)$, $(62.5 \%)$ are non-resident in the study area but uses the roads, while $55.6 \%$ representing are high users of the roads. In term of the trip purpose $40.1 \%$ are home-base i.e residents in the area, $54.5 \%$ of the respondents usually use their personal vehicles. Also, $70.9 \%$ preferred to pay the toll fees in cash regardless of the discounts offered on E-Tags.

Consequently, $75.2 \%$ of the road users complained of non-availability of alternative routes that is a necessity in road concession agreements, 69.2\% respondents posited that they would not love to see other roads concession due to the bottlenecks and cost imposed on them. On the other hand, $46.7 \%$ opined that fuel tax should be used to finance highway construction and maintenance, while $35.2 \%$ stated that neither new nor existing highways should be tolled.

\subsection{Multiple Regression of Road Concessioning}

This study as shown in Table 5 revealed that road concessioning impacts journey time, safety measures and car fuelling and maintenance (CFM) costs incurred by the road users with the coefficient of determination $(\mathrm{R})$ value of 0.829 . The R-Square value of $68.4 \%$ was predicted from the road concessioning, the value explained the variance in the road users journey time, safety measures on the road that can benefit the road users, car fuelling and maintenance (CFM) costs. The F-value obtained is 251.154 at $5 \%$ significance level i.e $\mathrm{p}<0.05$. 
Table 5: Multiple Regression of Road Concessioning on Respondents Journey time, safety measures, and Car fuelling and maintenance (CFM) cost

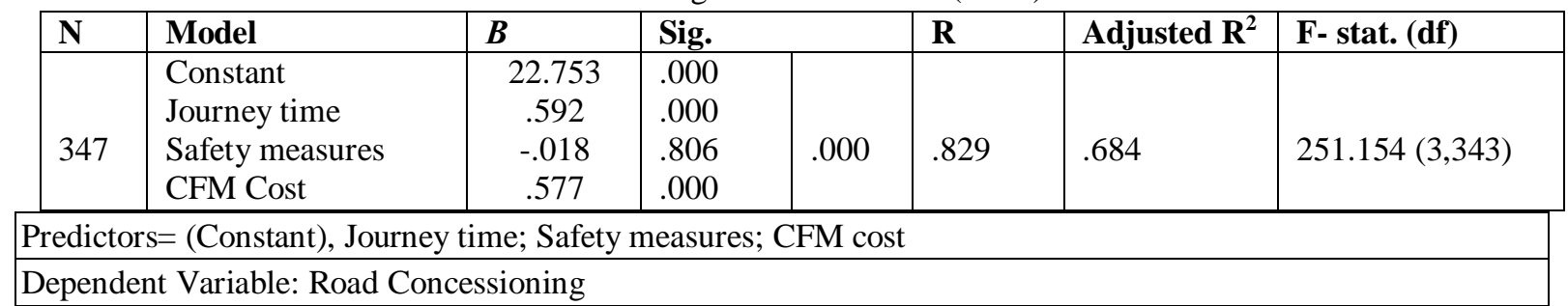

The concessioning equation is given as follows:

$Y=22.753+0.592 X_{1}-0.018 X_{2}+0.577 X_{3}$

Where:

$\mathrm{Y}=$ Road Concessioning; $\mathrm{X}_{1}=$ Journey times; $\mathrm{X}_{2}=$ Safety measures; $\mathrm{X}_{3}=\mathrm{CFM}$ cost

From equation 1.0, the journey time is highly significant in predicting the road concessioning while safety measures are the least predictor variable.

\subsection{Artificial Neural Network (Multilayer} Perceptron) Analysis

The model summary in Table 6 shows that the sum of squares error in the training is 29.087 and in testing of 14.821 phases are acceptable with the relative error in both phases remaining at 0.284 . The architecture diagram (Figure 5) when the synaptic weight $<0$ shows higher relationship between the independent variable of journey time and road concessioning. This is supported by the parameter estimates in both the hidden and output layers of the analysis as it has a predictor value of $-1.063,-0.966$, -0.309 and 0.102 in layers $\mathrm{H}_{1}, \mathrm{H}_{2}, \mathrm{H}_{3}$ and $\mathrm{H}_{4}$ respectively as shown in Table 7 .

Table 6: Model Summary for the Artificial Neural Network (ANN) Analysis

\begin{tabular}{lll}
\hline Training & $\begin{array}{l}\text { Sum of Squares Error } \\
\text { Relative Error }\end{array}$ & $\begin{array}{l}29.087 \\
.248\end{array}$ \\
Testing & Stopping Rule Used & $\begin{array}{l}1 \text { consecutive step(s) } 1 \text { consecutive } \\
\text { step(s) with no decrease in error }\end{array}$ \\
& & \\
& Training Time & $0: 00: 00.45$ \\
& $\begin{array}{l}\text { Sum of Squares Error } \\
\text { Relative Error }\end{array}$ & 14.821 \\
& & .284 \\
\hline
\end{tabular}

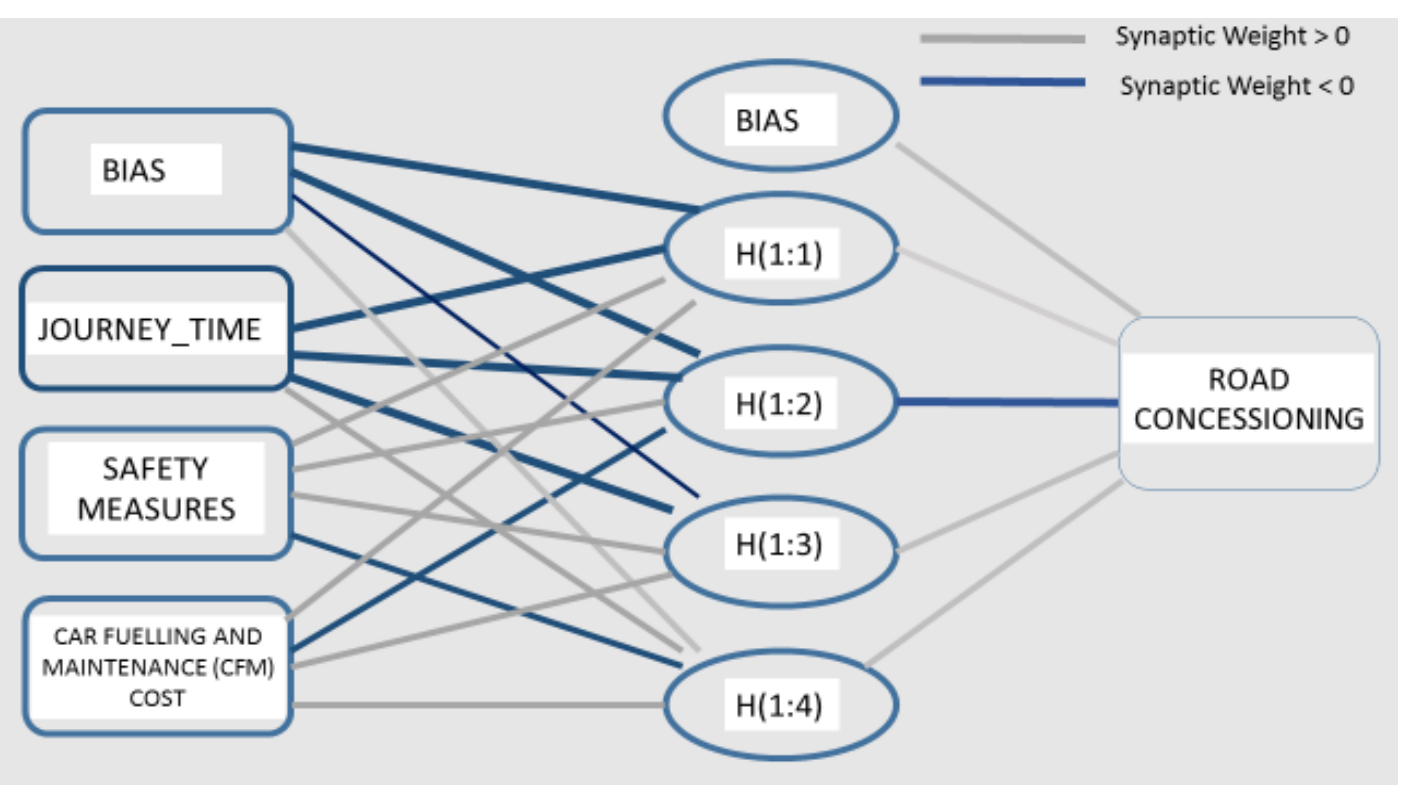

Hidden layer activation function: Hyperbolic tangent Output layer activation function: identity Figure 5: Artificial Neural Network (ANN) Architecture Diagram 
International Journal of Engineering Applied Sciences and Technology, 2020

Vol. 4, Issue 10, ISSN No. 2455-2143, Pages 363-371

Published Online February 2020 in IJEAST (http://www.ijeast.com)

Table 7: Parameter Estimates of both the Predictor and Predicted Variables

\begin{tabular}{lllllll}
\hline Predictor & & \multicolumn{3}{c}{ Hidden Layer } & Outer Layer \\
\cline { 3 - 7 } & & $\mathbf{H}(\mathbf{1 : 1})$ & $\mathbf{H}(\mathbf{1 : 2})$ & $\mathbf{H}(\mathbf{1 : 3})$ & $\mathbf{H}(\mathbf{1 : 4})$ & Road Concessionir \\
\hline Input Layer & (Bias) & -.889 & -.321 & -.079 & .326 & \\
& Journey time & -1.257 & -.966 & -.309 & .102 & \\
& Safety Measures & .228 & .628 & .300 & -.098 & \\
Car Cost & & -.183 & .097 & .367 & .136 \\
Hidden Layer & H $(1: 1)$ & & & & & 1.131 \\
& $\mathrm{H}(1: 2)$ & & & & -1.535 \\
& $\mathrm{H}(1: 3)$ & & & & -.016 \\
& $\mathrm{H}(1: 4)$ & & & & .151 \\
\hline
\end{tabular}

The independent variable importance agrees with the result from multiple regression (Table 5) that journey time and cost of car maintenance and fuelling of the road users have been significantly reduced by the improved condition of the road by concessioning. The result as shown in Table 8 and Figure 6 also reveals that road concessioning has affected the journey time of the respondents by 0.378 while it affects cost of car maintenance and fuelling by 0.405 in the order of its importance.

Table 8: Independent Variable Importance

\begin{tabular}{lll}
\hline & Importance & Normalized Importance \\
\hline Journey_Time & .378 & $93.3 \%$ \\
Safety_Measures & .216 & $53.4 \%$ \\
CFM_Cost & .405 & $100.0 \%$ \\
\hline
\end{tabular}

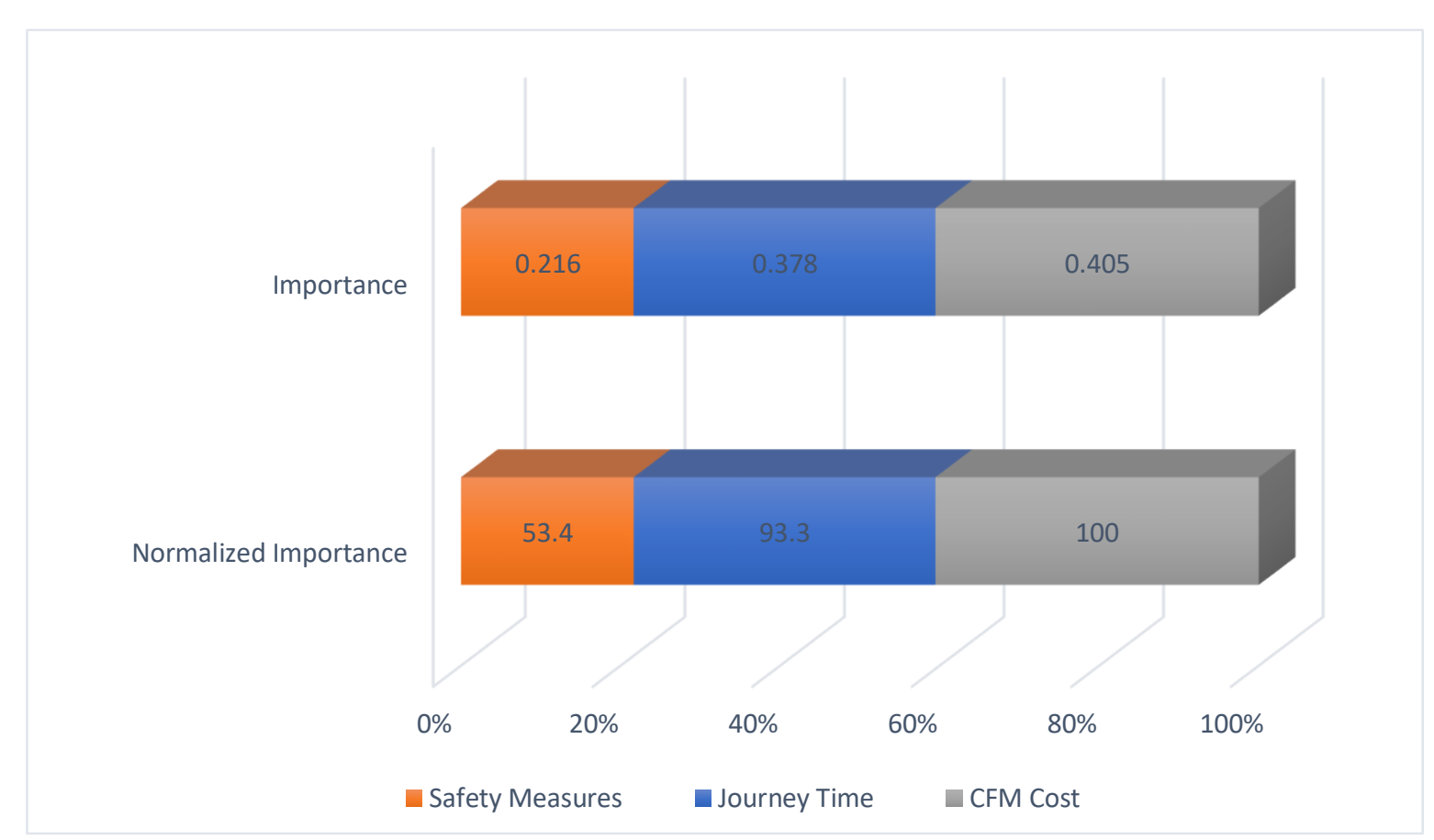

Figure 6: Normalized Importance Rating for The Independent Variables.

\section{CONCLUSION}

Road networks are important for every nation's prosperity and economic development; however, many developing countries are suffering from deplorable road networks which have undermined their prosperity. Government budgets are lean and cannot accommodate the high cost associated with road construction and maintenance that now gives rise to road concessioning. Road users sometimes disagree with having to pay additional tolls on roads which, they believe are basic infrastructures government should provide. However, the study shows that road concessioning significantly affects road users journey time as it is being reduced when the road condition is good. The car maintenance and fuelling (CFM) cost is also reduced as ravelling, cracking, potholes, rutting and other defects are reduced. Road safety also increases with provision of concrete barriers, lightings, security patrols that makes use of the roads safe. The recent move by the government of Nigeria to allow for the construction of 


\section{International Journal of Engineering Applied Sciences and Technology, 2020 \\ Vol. 4, Issue 10, ISSN No. 2455-2143, Pages 363-371 \\ Published Online February 2020 in IJEAST (http://www.ijeast.com)}

public roads by private entities and granting them tax waiver is a welcome development. The study recommends that other options of road infrastructure financing such as the Build, Operate and Transfer should also be considered and the tolling /concessioning period needs to be properly defined. Also, multimodal systems of transportation should also be enhanced in developing countries to alleviate the stress imposed on road pavements that thereby hastens their deterioration.

\section{REFERENCES}

[1] Adanikin, A. \& Oyedepo, J. (2017). Public Transportation Policy in Developing Countries - Nigeria as a Case Study. International Conference on Management, Technology and Sustainable Development (SMAT FUTA).

[2] ASECAP (2014). Evaluation and future of road toll concessions. PricewaterhouseCoopers Advisory S.p.A.

[3] Brushett, S. (2005). Management and financing of road transport infrastructure in Africa (English). Road Management and Financing; Discussion Paper no.4. Washington, DC: World Bank.

http://documents.worldbank.org/curated/en/607 371468203352035/Management-andfinancing-of-road-transport-infrastructure-inAfrica

[4] Harral, C., Smith, G., Paterson, W. \& Queiroz, C. (2011). Maintaining road assets: A fresh look at the World Bank's 1988-policy paper "road deterioration in developing countries". Transport Research Support, 1-71.

[5] IER (2002). Is Ukraine prepared to implement highway concessions? Retrieved from: www.ier.com.ua/files/publications/Policy_pape rs/German_advisory_group/2001/Q12_eng.pdf

[6] Jerome, A. (2004) Infrastructure Privatization and Liberalization in Africa: Centre on Regulation and Competition 3rd International Conference, Pro-poor regulation and competition: Issues, policies and practices, Cape Town, South Africa.

[7] LCC (2019). Tariff list. https://www.lcc.com.ng/tariffslist.asp

[8] Loto, M. A., \& Nkaogu, C. V. (2013). Infrastructural development in Nigeria: A study of the Lekki Epe Expressway: (The CostBenefit Analysis between 2010 - 2040). A 30Year period analysis. American Journal of Economics, 3(1), 32-42.

[9] Nairametrics (2017). Lagos state government to increase Lekki toll fares from January $1^{\text {st }} 2018$. https://nairametrics.com/2017/12/24/lagosstate-government-to-increase-lekki-toll-faresfrom-january-1st-2018/
[10] Opawole, A., Jagboro, G.O., Babatunde, S.O., \& Opawole, M O. (2013). Critical factors in road infrastructure development in Osun state, south-western Nigeria. International Journal of Development and Sustainability, 2(1), 240-253.

[11] Opuiyo, O. (2015). Innovative Financing to Meet Growing Transport Demand in Africa. Presentation to AfDB Transport Forum. Retrieved from www.afdb.org/fileadmin/uploads/afdb/Docume nts/Generic-

Documents/fDB_Transport_Forum_2015_Report.pdf

[12] Pojani, D. \& Stead, D. (2015). Sustainable Urban Transport in the Developing World: Beyond Megacities. Sustainability, 7, 77847805

[13] Pulseng (2018). Buhari presents n883 trillion 2019 budget to national assembly. https://www.pulse.ng/news/local/buharipresents-n883-trillion-2019-budget-to-nationalassembly/ydpmpkg

[14] Royal Institute of Chartered Surveyors -RICS (2011). RICS Research: The Future of Private Finance Initiative and Public Private Partnerships. RICS, London UK.

[15] The Nation (2016). Lekki-Epe expressway tolling begins at tp2. http://thenationonlineng.net/lekki-epeexpressway-tolling-begins-at-tp2-december-16/ [16] Wikipedia (2019). Lagos State. Retrieved from: https://en.m.wikipedia.org/wiki/lagos_State

[17] Wong, E.S., Then, D., \& Skitmore, M (2000) Antecedents of Trust in Intra-Organizational Relationships within Three Singapore Public Sector Construction Project Management Agencies, Construction Management Economics, 18, 797-806 